\title{
Изучение распространения и генетического разнообразия Phaeomoniella chlamydospora и Phaeoacremonium aleophilum на территории виноградных насаждений Краснодарского края и Крыма
}

Блинова С.А. ${ }^{1,2 *}$, Шварцев А.А. ${ }^{1}$, Странишевская Е.П. ${ }^{3}$, Володин В.А. ${ }^{3}$, Ильницкая Е.Т. ${ }^{4}$, Макаркина М.В. ${ }^{4}$, Алексеев Я.И. ${ }^{1,3}$

${ }^{1}$ ООО «Синтол», Москва, Россия

2 ФГБНУ ВНИИСБ, Москва, Россия

${ }^{3}$ ВННИИВиВ «Магарач» РАН, Ялта, Республика Крым

${ }^{4}$ ФГБНУ СКФНЦСВВ, Краснодар, Россия

*e-mail: Sofya.blinova@yandex.ru

Ключевые слова: ПЦР, генотипирование, скрининг, эска, болезнь Петри

Мотивация и иель: Болезни Петри и эска являются сдерживающим фактором для производства винограда по всему миру (Chiarappa, 2000). К настоящему времени на территории России не проводилось скрининговых исследований распространения возбудителей болезней Петри и эска с использованием молекулярно-генетических методов. В нашем исследовании был проведен скрининг Phaeomoniella chlamydospora и Phaeoacremonium aleophilum на территории виноградников Краснодарского края и южного берега полуострова Крым, изучена их локализация в лозе винограда, а также проведено генетическое типирование выявленных изолятов Phaeoacremonium aleophilum.

Meтоды и алгоритмы: Количество образцов винограда для исследования составило 190 шт. Для определения локализации патогенов в растительном материале было проведено выделение НК из трех частей одной лозы. Статистическая обработка данных проводилась в приложении RStudio ver. 8.12.175.481. Скрининг образцов винограда на наличие целевых грибов проводили методом ПЦР с последующей визуализацией продуктов амплификации на приборе НАНОФОР 05.

Результаты: Использованная в работе система праймеров позволяет проводить эффективное выявление Phaeoacremonium aleophilum и Phaeomoniella chlamydospora в том числе и на бессимптомных лозах.

В ходе исследования установлены места локализации целевых грибов, которые со статистической значимостью преимущественно концентрируются в проводящей системе растений. Результаты нашего исследования позволяют рекомендовать использование в качестве образца для выделения проводящую систему винограда для выявления Phaeoacremonium aleophilum и Phaeomoniella chlamydospora.

При генотипировании выявленных образцов Phaeoacremonium aleophilum не выявлено ни одного изолята повторяющего полностью все нуклеотидные замены выложенных в базе GeneBank штаммов.

Список литературы

1. Chiarappa, L. (2000): Esca (black measles) of grapevine. An overview. Phytopathol Mediterranea. 2000;39(1):11-15. 